\title{
BEING AN ENGLISHTEACHER IN INDUSTRIAL REVOLUTION 4.0: AN OVERVIEW ABOUT ROLES, CHALLENGES, AND IMPLICATIONS
}

\author{
L. Angelianawati \\ angelianawati@gmail.com \\ Universitas Kristen Indonesia
}

\begin{abstract}
ABSTRAK
Perkembangan ilmu pengetahuan dan teknologi yang sangat pesat di era revolusi industri 4.0, berdampak luar biasa terhadap kehidupan manusia, salah satunya pada bidang Pendidikan. Teknologi digital berimbas pada system pendidikan di Indonesia, khususnya Bahasa Inggris, mengingatkemampuan berkomunikasi bahasa asing menjadi bagian tak terpisahkan dari pemanfaatan teknologi. Dalam hal ini, guru Bahasa Inggris memiliki peran yang dapat menentukan keberhasilan pendidikan bahasa. Peran-peran tersebut dapat memperlengkapi siswa-siswi dengan literasi baru meliputi literasi data, teknologi, dan sumber daya manusia, keterampilan, dan karakter bangsa sehingga mereka bias menjadi agen perubahan yang bijaksana dalam menyikapi dan menggunakan kecanggihan teknologi, dengan tetap memperhatikan nilai kemanusian. Meskipun memberikan banyak manfaat bagi kehidupan dan menyediakan kemudahan bagi manusia, revolusi industry ini memberikan tantangan yang cukup kompleks pada para praktisi pendidikan, khususnya para guru Bahasa Inggris. Selainitu, revolusi ini juga membawa implikasi pada dunia pendidikan, terutamanya pada pembelajaran Bahasa.
\end{abstract}

Kata kunci: guru Bahasa Inggris, Revolusilndustri 4.0, peran

\begin{abstract}
The rapid development of science and technology in the era of industrial revolution 4.0, has tremendous impacts on human life, one of them in the field of Education. Digital technology causes a shift on the education system in Indonesia, especially English education, since the ability to communicate in foreign languages is an integral part of the technology utilization. In this case, English teachers have particular roleswhich can determine the success of the language education. These roles can equip students with new literacies including data literacy, technology literacy, and human literacy, skills, and national characters, which make them become wise agents of change in addressing and using technological sophistication, without neglecting human values. Although, it provides many benefits and conveniencesfor human beings, this industrial revolution provides quite complex challenges for education practitioners,
\end{abstract}


Angelianawati, Being an English teacher in Industrial Revolution 4.0: An Overview about Roles, Challenges, and Implications

especially English teachers. In addition, this revolution also bears implications toward the world of education, especially in language learning.

Key words: English teacher, Industrial Revolution 4.0, roles

\section{INTRODUCTION}

The recent rapid advancement of technologies provides everyone with many new capabilities and, at the same time, changes the ways people live, study, work, and interact with others, as Schwab (2017) signifies that the new industrial revolution with its "fusion of technologies across the physical, digital, and biological worlds" (p.1) causes shifts not only across all industries, but also towards society, and reshapes governments, institutions, systems of education, and many others. This industrial era requires people to have creative insight, collaborative team work, and adaptivity toward culture differences, including intercultural and interpersonal skills (Penprase, 2018). In the framework of English education, especially in the teaching and learning context, this circumstanceindicates that English teachers have to develop interactive forms of pedagogy and put emphasizes on multiple disciplinaries and cultural perspectives, in order to cultivate students [human] capacities and skills, as well as their language proficiency. It appears that selfdirected learning and thinking also should be well-developed since technologies are exponentially developed and require people to update their skills and teach themselves about the latest technologies and industries continuously. It is in line with what Wheelers (2013) suggests about pedagogy [education] that "Pedagogy is leading people to a place where they can learn for themselves. It is about creating environments and situations where people can draw out from within themselves, and hone the abilities they already have, to create their own knowledge, interpret the world in their own unique ways, and ultimately realize their full potential as human beings"(para. $3)$.

The rapid growth of technological innovations and industries bring great impacts on English education in Indonesia. Schwab (2017) signifies that the era of education driven by the industrial revolution 4.0 was called Education 4.0. Education 4.0 is education which responds to the needs on Industry 4.0 where smart machines work alongside human-professionals, utilizes the potentials of digital technologies, personalized data, open sourced contents, and the globally-connected, technologyfuelled world of humanity, and establishes lifelong learning to grow and survive even to play a 
better role in the society (Fisk, 2017).Digital learning process in the era of Industrial Revolution 4.0 demands curriculum reorientation, hybrid / blended learning, and life-long learning (Ahmad, 2018). It urges schools in Indonesia, namely English teachers, to be adaptable toward technological advancement and be able to use it, as well as to build a lifelong learning, since it helps students facing and adapting the future changes. Furthermore, longstanding literacies covering reading, writing, and mathematics are not sufficient for living in the society. New literacies are needed as assets to encounter the era of Industrial Revolution 4.0. Aoun (2017) proposes three new literacies i.e. data literacy, technological literacy, and human literacy, which prepares students to compete in a labor market in which smart machines work alongside human. Students are expected to have the capabilities of reading, analyzing, and utilizing information (big data) in the digital world-it is called data literacy; students also should have technological literacy, and understand how machines works, and technological applications, such as coding, artificial intelligent $(\mathrm{Al})$, and engineering principles; and human literacy the humanities, communication, and design - should be owned by students to function as a human being. Human literacy is important to survive in this era, the goal is so that students can function well in their environments and societies. This circumstance shows the need for change in the field of English language teaching and learning. Schools are expected to develop data literacy, technological literacy, and human literacy. Within the industrial revolution 4.0 , students are expected to be equipped with literacies which make them survive within the rapid growth of science and technologies.

Regarding to the rapid growth of science and technology in the context of schooling in Industrial revolution 4.0, English teachers appear to have a great number of roles toward the successfulness of the students in English learning, since they can equip students with capacities for living and working through and within the rapid changes of technologies and industries (Aoun, 2017). Fullan (1993) also suggests that teaching is to prepare students for a real world in the future and bring about meaningful change, by striving to become effective at managing the changes itself. This implies that an English teacher is an agent of change needed by the students to grow and survive within the revolution.

Additionally, an English teacher is a preferable profession recently. However, just a number of people realize the roles incurred by the profession. According to Pullias and Young (1977), being a teacher makes a person become many things and may become a major factor which influence the future. It seems 
important to examine more deeply about the roles of teachers, especially English teachers, in education, namely in the era of Industry 4.0. Therefore, in this writing, an elaborate explanation about teachers' roles is given, including challenges and the implications of Industry 4.0 toward the English teachers.

\section{DISCUSSION}

Teacher Roles

A role is defined as "a comprehensive pattern of behaviour that is socially recognized, providing a means of identifying and placing an individual in a society. It also serves as a strategy for coping with recurrent situations and dealing with the roles of others' (Role, 2019). It implies that a role is a function or action assumed or played by a certain person in a particular situation or context. In accordance with an English teacher as a profession, it appears that the teacher bears many roles embed to the profession itself. Harmer (2007) states ".... good teacher's art is the ability to adopt a number of different roles in the class, depending on what the students are doing" (p.25). He signifies that in teaching English, a teacher must be able to adopt certain roles for a particular context of learning.

In correlation to the fusion of digital learning technologies within the system of education in the era of Industry 4.0, English teachers are expected to have and be aware of the appropriate roles to be played during the lesson.Harmer (2007, 2012, 2015)proposes some teacher roles, which should be brought into actions depending on the learning objectives and classroom activities, namely as controller, monitor and evidence gatherer, feedback provider, prompter and editor, resource and tutor, organiser or tasksetter, comprehensible input provider, and facilitator. Becoming a controller, the teacher is the focus of attention, dictates everything, and provides a little chance for the students to be responsible for their own learning. As a monitor and evidence gatherer, the teacher keeps an eye on what happens in the class, and collects information about the students' progressiveness in language learning. A feedback provider is the teacher's role when gives feedbacks toward students' performances using the language, based on the evidences gathered previously. A prompter and editor are the next teacher roles, when the teacher encourages, motivates, and suggests the students about what to do next through the process of editing-suggesting chances for the betterment of the students' performances in English. As a resource and tutor, the teacher becomes the source of language information and guidance, andas advisor who responds to the students' learning and gives advice when it is needed.An organizer and task-setter are the teacher's roles when organizes 
tasks for the students, instructs the student clearly regarding to the tasks distributed, and arranges feedbacks on the activities/lessons. One of the most important role of the teacher is comprehensible input provider, who help the students improving their language acquisition through an active learning or communication using the language. The other role of a teacher is becoming a facilitator, who assists the students achieving their learning objectives by coaching, teaching, or mentoring, and makes learning take place in a proper way.

Additionally, there are many other teacher roles which remain adaptable to be played by the teachers in the classroom nowadays-inthe era of disruptive learning. Pullias and Young (1977) have mentioned many teacher roles, which are still adopted by teachers in order to equip students with knowledge, skills, and personality traits, and characters to face the Revolution Industry 4.0, specifically as a guide, a teacher, a modernisera bridge between generations, a model, a searcher, a counsellor, a creator-a stimulator of creativity, an authority, an inspirer of vision, a doer of routine, a breaker of camp-a mover-on, a storyteller, an actor, a scene designer-a creator of setting and mood, a builder of community, a learner, a facer of reality, an emancipator, an evaluator, a conserver-one who redeems and saves, a culminator-a time setter and planner, and a person-growing toward excellence within teaching,

\section{Roles of an Interactive Teacher}

In the era of Industry 4.0, students will interact actively andrapidly with technologies. This interaction is a promising engagement for successful language learning when it is effectively managed by teachers. Brown (2001) affirms that interaction is the core of communication, since it covers 'collaborative exchange of thoughts, feeling, or ideas among people' (p. 165). This interactivity is in line with the goal of human literacy, which requires students to be humanistic, have communicative skills and creativities. This circumstance urges English teachers to develop an effective interaction within the language learning in order to make it successful, as well as develop students' humanistic literacy.

Teachers have several roles, regarding to their responsibility to build meaningful interactions within language learning which is adaptable to Industry 4.0, namely as controller, director, manager, facilitator, and resource; teacher as controller means the teacher must be able to create a climate where spontaneous interactions utilizing the language can take place and predicted; teacher as director implies that the teacher must capable to direct or keep the language learning running smoothly, efficiently, and 
communicatively as a real-life like atmosphere; teacher as manager indicates that the teacher is the one who plans the lessons, teaching materials aids, without obstructing the creativities of the learners;teacher as facilitator signifies that a teacher must facilitate the learning processes, and make the learning itself easier by giving student guidance; and teacher as resource denotes that a teacher should provide students his/her availability - the teacher must be available for advising and counselling the students, and allow the students to proceed to the teacher with regard to their initiatives.(Brown, 2001, pp. 167168)

\section{Challenges of becoming an English teacher in Industrial revolution}

English teachers may come across challenges within the process of English language teaching, especially now-when technologies and innovations grow rapidly. Brown (2001) states that when someone chooses to be a language teacher, he may encounter challenges more than what is expected as he should assist learners[students] to learn English as a foreign language successfully. In the context of education 4.0, Zimmerman (as cited in Pannen, 2018) acclaims that students must be provided with particular capacities involving scientific skills, technology, engineering and mathematics, the internet of things, and lifelong learning, where in English teachers are challenged in many ways. Those pressures push the English teachers to adjust their roles within language learning, in order to fulfil their responsibility of becoming English teachers. Additionally, the roles played by a teacher in the learning processes develop an engagement between the teacher and students which may produce a harmony of powerful learning, or disagreement, rejection and disinterest (Zevin, 2010). Henceforth, it can be inferred that how teachers position themselves in the learning process, influence the learning itself. In other words, the teachers are challenged to be very selective in choosing the roles they bring into the class or the lesson. They are also expected to arrange the lesson thoughtfully involving the instructions and contentsknowledge, skills, and attitudes, which can equip students with characters and literacies to deal with the industrious world of technology.

Recently, students are living within digital world; they are surrounded by industries and technology advancements. These conditions require teachers to arrange lessons which utilize the innovations provided by the technology itself, which meet the need of Industrial Revolution 4.0, i.e. conducting hybrid/blende learning and online learning. Accordingly, the teachers are challenged to occupy themselves with ICT-literacy. Besides, 


\begin{abstract}
Schwab (2017) affirms that Industry $\quad 4.0 \quad$ generates continuous changesin wideranging fields and rapid emergences of technology breakthroughs. Therefore, a lifelong learning should be endeavoured and maintained, and curriculum needs adjustment to meet therequirements of Education 4.0, as a part of Industrial Revolution 4.0,that "develops both technical mastery and a deep awareness of ethical responsibility toward the human condition" (Penprase, 2018). The previous challenges becometasks for the educational practitioners to deal with. Further studies seem needed to beexecuted in order to find the best ways to resolve the challenges due to the Industrial revolution 4.0 .
\end{abstract}

\section{Implications of Industry 4.0 towards English Teachers}

Industry 4.0 brings several
implications towards English
teacher covering English
competencies, formal teacher
education, and teachers'
professional development. First,
regarding to English
competencies, teachers need to
be proficient in using spoken and
written English productively to
deliver English lessons and to
manage classes, and need to be
IT-literate. Second, in the context
of formal education, English
teachers should revisit the
curriculum and evaluate the
lessons, and all related matters,
which are expected to fulfil the
requirements of English
education in the era of Industry

4.0. English teachers must know and have accesses to technology-oriented professional development, and be able to teach and share knowledge through current ICT and social media communicatively and intellectually. Furthermore, since the teachers are expected to be the agents of social change, they must capable developing learning activities which require students to practice a lot not only at school abut also outside of school that may develop community engagement. The rapid growth of technology and science also push the teachers to be tenacious in improving their professionalism in order to encounter the globallyconnected education in the era of Industry 4.0. In this case, teachers are advised to collaborate with professional English teacher or teaching organization. Third, in terms of teachers' professional development, English teachers must be qualified and having the competencies to be professional English teachers-they should continuously upgrade their skills, which are in line with the digital technology advancement. The teachers may strive for professionalism by joining English teacher forums, building selfmotivation, joining both formal and informal professional development activities, such as: workshops, trainings, seminars, conferences, and researches. At last, teachers also should conduct reflective teaching to ensure that their professionalism develops and meets the 
Angelianawati, Being an English teacher in Industrial Revolution 4.0: An Overview about Roles, Challenges, and Implications

expectation of the latest Educational world.

\section{Additionally,Schwab}

(2017) mentions that Industrial Revolution 4.0 brings impacts toward individual, covering identity, moral, and ethics, human connection, and management of public and private information. Since an English teacher is a person (individual), these impacts are also applicable to English teachers. Technology enables English teachers to do things easier, faster, and in more efficient ways, as well as provides the teachers opportunities for personal development. However, it leads the teachers to a rapid change of technologies which demands continuous adaptations. As a consequence, some teachers may resist it and are unable to follow the changes, which results in a gap of technologies. Moreover, identity, moral, and ethics may become debatable issues, since the advancement of technologies, such as artificial Intelligent, internet, synthetic biology may replace the existence of teachers, even diminish human capacities. This implies that the teachers must maintain and endeavour human characters withinteaching and learning processes to make themselves as well as the students ready to work together with smart machines, without losing their human characters.Next, the industrial revolution tightens the individual and collective relationship with technologies. This condition may negatively influence the social skills and ability to empathize.This condition urges the teachers to take actions such as planning, instructing, and administering assignments which support the collaborative works and social interactions of the students within the technology based learning.The globallyconnected technology advancement also requires people to manage their public and private information wisely. Therefore, while utilizing technological applications for teaching, the English teachers must be selective and wise in sharing information namely when it relates to personal data, to avoid misuses of personal data.

\section{CONCLUSION}

Industrial revolution 4.0, arouses the need for optimizing the roles of teachers in English language learning, since the teachers as the agents of change in Education areneeded by the students to grow and survive within the revolution. There are many roles of teachers, for example as controllers, monitor and evidence gatherers, feedback providers, prompter and editors, resource and tutor, organizer or task-setter, comprehensible input provider, and facilitator, etc. In this case, the English teachers must be able to determine which roles to be employed in a particular context of learning, pertaining to the learning objectives and activities planned to be carried 
out by students within the globally-connected, technologybased learning. The industrial revolution brings about challenges and implications, including the need to improve English proficiency, formal teacher education, teacher's professional development, and also some individual issues.

\section{REFERENCES}

Ahmad, I. (2018, February 16). Pendidikan tinggi "4.0" yang mampu meningkatkan daya saing bangsa. Makassar, Indonesia: Belmawa Ristekdikti. Retrieved January 14, 2019, from https://fri2018.unhas.ac.id/ wpcontent/uploads/2018/02/P resentasi-Intan-Ahmad.pdf Aoun, J. E. (2017). Robot-proof: Higher education in the age of artificial intelligence. Cambridge: The MIT Press. Retrieved from https://muse.jhu.edu/book/ 55644

Brown, H. D. (2001). Teaching by principles: An interactive approach to language pedagogy. San Fransisco: Longman.

Fisk, P. (2017, January 24). Education 4.0 ... the future of learning will be dramatically different, in school and throughout life. Retrieved from https://www.thegeniuswork s.com/2017/01/future- education-youngeveryone-taught-together/ Fullan, M. G. (1993, March). Why teachers must become change agents.

Educational Leadership, 50(6). Retrieved January 14, 2019, from https://michaelfullan.ca/wp

content/uploads/2016/06/1 3396031680.pdf

Harmer, J. (2007). How to teach English. Harlow, England: Pearson Education.

Harmer, J. (2012). Teacher knowledge: Core concepts in English Language Teaching. Edinburgh, England: Pearson Education.

Harmer, J. (2015). The practice of English language teaching (5th ed.). Harlow, Essex, England: Pearson Education.

Pannen, P. (2018).

Mempersiapkan SDM Indonesia di era lindustri 4.0. Jakarta, Indonesia: Ministry of Research, Technology, and Higher Education. Retrieved from http://sdgcenter.unpad.ac.i d/wpcontent/uploads/2018/09/K emenristekdiktiMempersiapkan-SDMIndonesia-di-Era-Industri4.0.pdf

Penprase, B. E. (2018). The fourth industrial revolution and higher education. In N. W. Gleason, Higher education in the era of the fourth industrial revolution 
Angelianawati, Being an English teacher in Industrial Revolution 4.0: An Overview about Roles, Challenges, and Implications

(pp. 207-229). Singapore:

Palgrave Macmillan.

Pullias, E. V., \& Young, J. D.

(1977). A teacher is many things (2nd ed.).

Bloomington, United

States of America: Indiana University Press.

Role. (2019). Retrieved from

Encyclopaedia Britannica:

https://www.britannica.com /topic/role

Schwab, K. (2017). The fourth industrial revolution (1st ed.). New York: Crown

Business.

Wheeler, S. (2013, November 6).

The meaning of pedagogy.

Retrieved from

http://www.steve-

wheeler.co.uk/2013/11/the

-meaning-of-

pedagogy.html

Zevin, J. (2010). Teaching on a tightrope: The diverse roles of a great teacher. Lanham, UK: Rowman \& Littlefield Education. 